\title{
INCOME REDISTRIBUTION, BODY-PART REDISTRIBUTION, AND RESPECT FOR THE SEPARATENESS OF PERSONS
}

\author{
Joseph Mazor
}

$\longrightarrow$

7 HERE Is a broad consensus among both political philosophers and the general public that, though the redistribution of labor income is permissible, the redistribution of body parts is not. The question of why this is so, which I call the body-income puzzle, lies at the heart of several important debates regarding the distribution of human organs, just taxation, and the limits of what can be permissibly demanded of the advantaged. It will be my focus in this article.

Some scholars argue that there is no solution to the body-income puzzle. On this view, which is defended by both Robert Nozick and Cécile Fabre, there is no compelling, principled way of distinguishing the redistribution of labor income to the poor from the redistribution of nonessential body parts to the sick. ${ }^{1}$ Nozick and Fabre draw opposing conclusions from this position, with Nozick rejecting redistributive taxation and Fabre endorsing (at least in principle) the redistribution of certain nonessential body parts. However, the intuitive implausibility of both of these conclusions recommends the body-income puzzle for further investigation.

A variety of potential solutions to this puzzle have been proposed. Some argue that the solution lies in affirming individuals' self-ownership while denying individuals' ownership of their labor income. ${ }^{2}$ Others appeal to the particularly high welfare losses associated with bodily takings. ${ }^{3}$ I will argue that these solutions are unsuccessful.

I will argue instead that taking individuals' body parts is more objectionable than taking moderate percentages of their labor income because it constitutes a greater disrespect for their separateness as persons. Respect for the separateness of persons is the idea that each individual's life should be granted a certain

1 Nozick, Anarchy, State, and Utopia, 167-74, 205-6, 272-73. See also Fabre, Whose Body Is It Anyway? ch. 5 .

2 For a discussion of this approach and its proponents, see section 2.

3 For a discussion of this approach and its proponents, see section 3.1. 
primacy over the demands of the collective good. ${ }^{4}$ Such a primacy can be understood in terms of a sphere of moral authority that is protected from others' demands for assistance. The conception of respect for the separateness of persons that I defend holds that a person's body and her labor income both fall within this protected sphere of authority. And it views the strength of an individual's rights against interference in this sphere as non-absolute, variable, and dependent on consequences that the interference would have for the individual's personal identity. Since our body parts-even internal, nonessential onesare more intimately connected to our personal identity compared to moderate portions of our labor income, our separateness-based rights against body-part takings are particularly strong. Thus, while the weighty claims of the disadvantaged to assistance can justify the redistribution of substantial amounts of labor income, they are generally insufficiently weighty to justify the redistribution of substantial parts of others' bodies.

\section{THE BODY-INCOME PUZZLE}

Consider the following pair of cases:

Rich-Poor: Rich and Poor live in a society with plentiful arable land and no way of making a living other than farming it. Rich is an excellent farmer who can enjoy high income through just exchanges of his farming produce with others.

Poor is physically unable to farm intensively through no fault or choice of her own. She can eke out a marginal living, leaving her with poor nutrition, inadequate shelter, and no access to healthcare. Receiving 20 percent of Rich's income would enable Poor to lead a minimally flourishing life. ${ }^{5}$

Healthy-Sick: Healthy and Sick live in a society similar to that of Rich and Poor. Like Rich, Healthy is an excellent farmer who enjoys a high income. She has two well-functioning kidneys.

Sick suffers from kidney failure through no fault or choice of his own. In addition to a variety of maladies associated with kidney failure, Sick must endure dialysis several times per week. ${ }^{6}$ Sick's overall quality of

4 For a discussion, see Mack, "Non-Absolute Rights and Libertarian Taxation," 115-19. See also Zwolinski, "The Separateness of Persons and Liberal Theory," 150-53.

5 Fabre endorses a minimally flourishing life as the aim of redistribution (Whose Body Is It Anyway? 31). Readers with different views can adjust the examples accordingly.

6 For a description of dialysis, see National Kidney Foundation, "A 'New Normal.” 
life is thus very low-similar to that of Poor's. One of Healthy's kidneys would enable Sick to lead a minimally flourishing life.

This pair of cases brings the body-income puzzle into sharp relief. I take it that the state should redistribute 20 percent of Rich's labor income to Poor but should not redistribute Healthy's kidney to Sick. The puzzling question is this:

Body-Income Puzzle: Why should society condone substantial redistribution of labor income from the economically well-off to the indigent while rejecting the redistribution of nonessential body parts from the healthy to the infirm?

Any solution to this puzzle will have to meet several challenges. First (and most importantly), it will have to explain why the redistribution of nonessential body parts is more objectionable than the redistribution of labor income. Admittedly, an explanation of why the infirm's claims to assistance are weaker than the indigent's would also do. However, since many of those who need others' body parts are at least as heavily disadvantaged (often through no fault or choice of their own) as those who need financial assistance, this route to solving the body-income puzzle is unpromising, and I shall not consider it further here. ${ }^{7}$

Second, a solution to the body-income puzzle must grant body parts strong protection from redistribution. This is no easy task. It is not enough to offer some reason in favor of protecting body parts. The reason must be sufficiently weighty to justify resisting the infirm's pressing claims to assistance.

Third, a solution to the body-income puzzle must justify substantial levels of labor-income redistribution to the poor. This, too, is no easy task. After all, many theorists have argued that individuals have strong rights to the fruits of their labor-rights that are particularly difficult to deny while also affirming individuals' strong rights to their bodies. ${ }^{8}$

These are the three challenges posed directly by the body-income puzzle. However, a compelling solution to this puzzle must meet two additional challenges. First, it must place attractive limits on the protections offered to individuals' bodies. To see the need for such limits, consider the following case:

Drop of Blood to Save a Billion: A deadly pandemic has killed millions of people and is predicted to kill a billion more. The pandemic can only be stopped by studying a drop of blood from Adam (the sole survivor of the disease). Adam refuses to surrender a drop of his blood.

7 For a discussion, see Fabre, Whose Body Is It Anyway? 77.

8 See, for example, Wheeler, "Natural Property Rights as Body Rights." 
I take it that Adam can be permissibly coerced into surrendering a drop of blood in this case. Thus, while a theory of distributive justice that condemned all violations of the body, no matter how minor and no matter what else was at stake, could technically solve the body-income puzzle, such a solution would be uncompelling.

A compelling solution to the body-income puzzle must also place attractive limits on labor-income taxation. To see the need for such limits, consider the following policy:

Two-Kidney Tax: In Healthy-Sick, above, the state does not demand that Healthy surrender her kidney. Instead, it requires any person with two healthy kidneys to turn over all of her labor income to the state. Faced with this tax, Healthy transfers one of her kidneys to Sick.

I take it that this Two-Kidney Tax is impermissible. Thus, while a theory of distributive justice that offered no protections whatsoever to individuals' labor income could technically solve the body-income puzzle, such a solution would not be compelling, either.

\section{INCOME-EXCLUSION SOLUTIONS}

I now turn to considering several proposed solutions to the body-income puzzle, beginning with (what I call) income-exclusion solutions. Proponents of these solutions affirm individuals' stringent self-ownership — their strong (but non-absolute), extensive, unconditional property rights to their bodies. ${ }^{9}$ But they deny that individuals own their labor income due to its reliance on the appropriation of the natural world, transactions with others, and/or government-provided goods. ${ }^{10}$ Thus, labor income (but not body parts) can be permissibly redistributed to alleviate others' disadvantage.

Though this type of solution has substantial prima facie plausibility, it fails to meet the challenges laid out in section 1 . First, the distinctions that income-exclusion solutions draw between labor income and body parts are dubious. As other critics have pointed out, like our labor income, our bodies also depend on natural and social inputs. ${ }^{11}$ After all, our bodies constantly regenerate, and the new cells are physically made up of molecules generated from the food we eat-

9 See, for example, Otsuka, Libertarianism without Inequality, 15.

See Otsuka, Libertarianism without Inequality, ch. 1; Vallentyne's view in Tideman and Vallentyne, "Left-Libertarianism and Global Justice"; Christman, "Self-Ownership, Equality, and the Structure of Property Rights," 30-31; Murphy and Nagel, The Myth of Ownership.

See Eyal, "Is the Body Special?" 236. 
food that we obtained via uses of the natural world, transactions with others, and/or uses of government-provided goods. If labor income's reliance on these inputs makes it liable to redistribution, it is unclear why the body's reliance on these inputs does not also make it liable to redistribution.

Proponents of income-exclusion solutions might respond by appealing to self-ownership, which protects food molecules from redistribution once they are part of our bodies. However, self-ownership does not preclude placing various redistributive demands on individuals' bodies as a condition of using natural or social inputs. Just as I can demand Healthy's kidney in exchange for, say, my apples without violating Healthy's self-ownership, so too a policy requiring Healthy to surrender her kidney as a condition of appropriating natural resources, transacting with others, or using government-provided goods would not violate Healthy's self-ownership.

Proponents of income-exclusion solutions might respond that, while self-ownership is technically consistent with placing body-part redistribution conditions on the use of natural and social inputs, the moral considerations underlying self-ownership rule out such conditions. However, this response is difficult to evaluate without a comprehensive justification for self-ownership-a justification that many proponents of income-exclusion solutions do not provide. ${ }^{12}$ And it is far from obvious that a justification for self-ownership that condemned placing body-part redistribution conditions on the use of natural and social inputs would condone placing labor-income redistribution conditions on the use of these inputs.

Another problem with income-exclusion solutions is that the redistribution of labor-generated wealth seems justified even when this wealth does not depend on natural and social inputs. Consider, for example, the following case:

Hairy-Bald: Hairy and Bald are both created ex nihilo with fully developed life plans. They do not need air, water, or external nutrition.

Detached hair is the only material that can be used to make goods. Hair removal is painless but laborious, knowledge for turning detached hair into goods is instinctive, and hair-made goods can be protected without state intervention.

Hairy has sufficient hair to enjoy a high living standard (similar to the standard enjoyed by Healthy and Rich). Hairy refuses to give or trade any of his detached hair.

Bald, who lacks hair through no fault or choice of her own, can only gather sufficient discarded hair to achieve a marginal living standard 
(similar to that of Poor and Sick). Twenty percent of Hairy's detached hair per year would enable Bald to lead a minimally flourishing life.

In this example, labor-generated wealth is produced independently of any social institutions, transactions, or uses of the natural world. ${ }^{13}$ If these factors' use is what fundamentally distinguishes labor income from body parts, then the redistribution of Hairy's detached hair should be impermissible. Yet I submit that the redistribution of Hairy's detached hair is permissible (for reasons that I discuss below).$^{14}$ If so, this suggests that income-exclusion solutions fail to capture the foundational moral distinction between labor-generated wealth and body parts when it comes to redistribution permissibility.

Another problem with income-exclusion solutions is the insufficient justification they offer for the protection level they grant to the body. The redistribution of Healthy's kidney can be rejected and the redistribution in Drop of Blood to Save a Billion can be endorsed if we accept that self-ownership is stringent but non-absolute. Yet proponents of income-exclusion solutions often merely assert this level of self-ownership stringency. ${ }^{15}$ It is thus unclear why self-ownership rights are sufficiently weighty to justify resisting Sick's weighty claims to Healthy's kidney but insufficiently weighty to protect Adam's drop of blood from the moral demands of the billion.

Finally, income-exclusion solutions are unable to offer attractive levels of protection to individuals' labor income. It is unclear, for example, how these solutions can reject the Two-Kidney Tax proposed above. After all, this tax does not infringe on Healthy's body. And if labor income is unowned and can therefore be distributed to help the disadvantaged, it is unclear why society should not structure the distribution of income so as to induce Healthy to transfer one of her kidneys to Sick.

Proponents of income-exclusion solutions might respond by appealing to Healthy's substantive self-ownership to reject this tax. While formal self-ownership protects individuals from bodily interference, substantive self-ownership grants individuals rights that enable them to make use (or to not have to make use) of their bodies in certain ways. Michael Otsuka, for example, endorses a principle of substantive self-ownership that grants individuals "rights over enough worldly resources to ensure that [they] will not be forced by necessity to come to the assistance of others in a manner involving the sacrifice of one's

13 The exception is space, which I will assume is perfectly plentiful.

14 See section 6.4.

15 See, for example, Otsuka, Libertarianism without Inequality, 15. For a more detailed argument for the need for a self-ownership stringency justification, see Lippert-Rasmussen, "Against Self-Ownership." 
life, limb, or labor." ${ }^{16}$ Since Healthy's life would presumably be threatened if she had to surrender all of her labor income to the government, the Two-Kidney Tax would violate Healthy's substantive self-ownership as Otsuka defines it.

However, appealing to substantive self-ownership to reject the Two-Kidney Tax is problematic for three reasons. First, while this tax may well undermine Healthy's substantive self-ownership, not implementing this tax seems to undermine Sick's substantive self-ownership to an even greater extent. After all, without Healthy's kidney, Sick will have to live with severe physical limitations as well as a substantial risk of death. Admittedly, Otsuka's conception of substantive self-ownership, which only grants individuals rights to "worldly resources" and is only concerned with protecting individuals from being forced to take certain actions, would not grant Sick claims to have the Two-Kidney Tax implemented. Yet it is unclear why substantive self-ownership should be defined in Otsuka's way. After all, a variety of values that could be used to justify substantive self-ownership (e.g., autonomy, self-determination) seem more heavily compromised by Sick's serious physical limitations and substantial risk of death than by Healthy's being forced by necessity to transfer one kidney to Sick. ${ }^{17}$

Second, even if the Two-Kidney Tax undermines Healthy's substantive self-ownership more than it fosters Sick's, this would still not necessarily justify rejecting this tax. After all, Sick presumably has powerful disadvantage-based moral claims to have this tax implemented (e.g., based on the very low welfare levels he must endure through no fault or choice of his own). Thus, unless it can be established that Healthy's substantive self-ownership has a great deal of moral weight (a task that Otsuka does not undertake), an appeal to Healthy's substantive self-ownership will be insufficient to reject the Two-Kidney Tax.

Finally, even if Otsuka could justify granting substantive self-ownership as he defines it a great deal of moral weight, this would still not ground intuitively compelling protections to individuals' labor income. To see why not, consider the following tax:

Two-Kidney Tax with a Necessitarian Cap: The government makes the Two-Kidney Tax somewhat less extreme by placing a cap on it. The capped tax would leave those who have two kidneys with just enough insubstantive self-ownership would be greater than the effects of not implementing the tax on Sick's substantive self-ownership. 
come to afford necessities if they refuse to surrender one of their kidneys.

To avoid this tax, Healthy transfers one of her kidneys to Sick.

I submit that, even with the cap, this two-kidney-based tax is impermissible. Yet this tax respects Healthy's substantive self-ownership as Otsuka defines it (since Healthy would not be forced by necessity to transfer body parts to anyone else). And while Otsuka could respond by adjusting his conception of substantive self-ownership to rule out this tax, it is not clear that substantive self-ownership can be compellingly defined in a way that simultaneously grants Healthy rights against the Two-Kidney Tax with a Necessitarian Cap, does not grant Sick even weightier rights to have this tax implemented, and does not protect Rich from labor-income taxation.

Proponents of income-exclusion solutions could alternatively reject heavy two-kidney-based taxation by setting limits on the amount of labor income that can be demanded of a person due to her use of natural and social inputs. Peter Vallentyne, for example, holds that an individual's redistributive tax burden should be limited by the market value of the natural resources she has appropriated. ${ }^{18}$ Since the market value of the plentiful arable land in Healthy-Sick is zero (or close to it), Vallentyne's proposal would protect Healthy from both the Two-Kidney Tax and the Two-Kidney Tax with a Necessitarian Cap.

However, Vallentyne's proposed limit is problematic for two reasons. First, he does not offer a principled justification for this limit. It is therefore unclear why this limit should be respected given the very weighty benefits that heavy two-kidney-based taxation would have for Sick. Second, while Vallentyne's limit rules out the unattractive two-kidney-based taxation, it also rules out attractive levels of redistributive taxation in certain cases. Note, for example, that the land in Rich-Poor is also plentiful and thus would have a market value of zero (or close to it). The level of labor-income redistribution permitted by Vallentyne's theory would therefore be insufficient to meet Poor's intuitively attractive claims to assistance in this case. Thus, it is far from obvious that attractive limits on labor-income taxation can be compellingly defended by proponents of income-exclusion solutions.

In sum, income-exclusion solutions seem incapable of meeting the challenges posed in section 1. The distinctions they draw between body parts and labor income are suspect. The protections they offer the body lack sufficient justification. And the protections they offer to labor income are either implausibly strong or implausibly weak. 
Other proposed solutions to the body-income puzzle do not deny that individuals have rights to their labor income. They aim instead to explain what it is about the infringement of individuals' rights to their body parts that is so much more objectionable than the infringement of their rights to their labor income. I call these body-specialness solutions. In this section, I criticize two prominent solutions of this sort.

\subsection{The Appeal to Welfare Loss}

The first solution I wish to consider appeals to the particularly high welfare loss associated with bodily takings. Note that even the taking of a nonessential, internal body part like a kidney entails considerable welfare loss. The kidney's loss imposes nonnegligible risks and lifestyle restrictions on the individual whose kidney is taken. ${ }^{19}$ The recovery from the operation is painful and involves considerable physical limitations. ${ }^{20}$ And the thought of someone else cutting deep into one's body to extract an organ is disconcerting and, for many, deeply humiliating. ${ }^{21}$ Perhaps, then, taking Healthy's kidney is more objectionable than taking Rich's labor income simply because it entails a greater loss of welfare.

However, this type of welfarist body-specialness solution faces several problems. First, even if welfarist considerations can explain why taking Healthy's kidney is more objectionable than taking Rich's income, these considerations cannot explain why Sick should be denied Healthy's kidney. After all, the welfare loss from having a kidney surgically removed cannot plausibly outweigh the welfare gain to Sick from no longer having to live with kidney failure, with the associated severe physical limitations, health problems, and routine bodily intrusions required by dialysis. ${ }^{22}$ Those who appeal to a welfarist account of the special objectionability of body-part takings will therefore need a non-welfarist account of individuals' rights to keep their body parts in the face of others' claims to assistance. Yet it is unclear how these two commitments can be compellingly combined.

A second problem with welfarist body-specialness solutions is that, as Fabre points out, the welfare loss associated with having certain body parts surgically removed (at least under modern medical conditions) does not seem to be

For a list of risks, see Johns Hopkins Medicine, "What to Expect as a Living Donor."

For a description of the recovery process, see Johns Hopkins Medicine, "What to Expect as a Living Donor."

Eyal, “Is the Body Special?" 237-38.

For a description, see National Kidney Foundation, "A 'New Normal." 
greater than the welfare loss associated with being deprived of, say, 20 percent of one's labor income annually. ${ }^{23}$ To make matters concrete, assume that Rich and Healthy have identical preferences, have a guaranteed pretax annual income of $\$ 100,000$, work for fifty years, can save and borrow as much money as they want at the going interest rate, and the interest rate and inflation rate are both zero. I take it that, even in this case, taking Healthy's kidney is more objectionable than taking 20 percent of Rich's annual income. Yet to explain why this is so, a proponent of a welfarist body-specialness solution would have to claim that taking Healthy's kidney entails a greater welfare loss than depriving Rich of $\$ 1$ million of lifetime earnings - ten years' salary. This seems difficult to accept.

Indeed, we need not rely solely on intuition to support this skepticism. Gary Becker and Julio Jorge Elias have estimated what it would take to induce a person to part with her kidney. The figure they defend is a lump sum of $\$ 15,200$ for a person with an annual income of $\$ 35,000$ (i.e., under half of one year's salary). ${ }^{24}$ Becker and Elias's estimate can admittedly be criticized for excluding several risks and negative consequences associated with surgical removal of a kidney. ${ }^{25}$ It will also need to be adjusted upward to take account of Rich's greater income. Yet it is difficult to believe that the appropriate adjustments would raise Becker and Elias's $\$ 15,200$ figure above $\$ 1$ million.

Moreover, even if taking Healthy's kidney constitutes a greater welfare loss than taking 20 percent of Rich's income, we can fairly easily imagine other cases in which taking body parts clearly entails a smaller welfare loss while nevertheless seeming more objectionable. Consider, for example, a variation of Rich-Poor in which Rich is an extreme miser who experiences very high welfare losses whenever any of his money is taken from him (assume also that Rich did not consciously develop his miserly attitude and cannot help it). I submit that the redistribution of 20 percent of Rich-the-miser's labor income to help Poor would nevertheless be permissible. Yet it is unclear how a proponent of a welfarist body-specialness solution can explain why this is so.

Alternatively, consider the following case:

Dismantling the Bedridden: Ben is suffering from an incurable but non-life-threatening brain tumor that routinely induces weeks-long peri-

24 Becker and Elias, "Introducing Incentives in the Market for Live and Cadaveric Organ Donations," 11.

25 See, for example, the discussion of mental health risks in section 5 below. Becker and Elias's estimate would also need to be adjusted upward due to the special welfare loss associated with a coerced taking of a kidney. 
ods of unconsciousness and requires Ben to remain hooked up to various machines.

Given his condition, Ben can be subjected to the taking of various body parts-a kidney, portions of his pancreas, liver lobes (multiple times once they regenerate), parts of a lung, and bone marrow (multiple times) - all without significant consequences for Ben's quality of life (as long as the takings occur during his periods of unconsciousness). Moreover, removing these body parts while Ben is alive substantially increases their usefulness to others.

Unbeknownst to Ben, his doctors remove these body parts (and replace them with biosafe materials to ensure the effects are unnoticeable).

I submit that Dismantling the Bedridden is highly objectionable. Yet taking Ben's organs has no discernable effect on Ben's health, quality of life, or self-conception. It is thus difficult to argue that Ben's welfare loss is greater than Rich's. If what is done to Ben is nevertheless more objectionable, this suggests that the greater protections due to the human body cannot be fundamentally grounded in the greater welfare loss associated with bodily takings.

\subsection{Personal Identity, Body Parts, and Labor Income}

A second body-specialness solution that can better contend with these types of cases is proposed by Margaret Radin in "Property and Personhood." ${ }^{26}$ Radin argues that a person's entitlement to a resource is stronger the more important the resource is to the individual's personal identity - to those features that make her the particular person that she is. ${ }^{27}$ In Radin's view, the features that define our personal identity include, not only the characteristics of our physical bodies, but also "our particular commitments and character traits, our particular memories and future plans, and our particular relationships with other people and with the world of external objects." 28

Radin then argues that a person's money is not as closely connected to her personal identity as her body is. A dollar, Radin points out, is only personally important due to what it can buy-one dollar bill is generally no more personally

Radin, "Property and Personhood."

Radin, "Property and Personhood," 986. Radin uses the term "personhood" to denote what I am calling "personal identity." I do not use the term "personhood" because it could misleadingly suggest that the protected resources are metaphysically part of the person. For a general discussion of personal identity in the sense used here, see Olson, "Personal Identity," sec. 1.

Radin, “Property and Personhood," 972. 
important than any other. ${ }^{29}$ On the other hand, we are constituted by our bodies, and our organs are thus intimately connected with our personal identity. ${ }^{30}$ The taking of our body parts therefore constitutes a greater personal violation-that is, it infringes in an unwelcome way on a right with greater importance to our personal identity — compared with the taking of our money—and is for that reason more objectionable. ${ }^{31}$

Importantly, Radin defends a conception of personal identity that is not purely subjective. ${ }^{32}$ This enables her to condone the taking of a miser's income, even if the miser feels an intimate personal connection with every dollar in his bank account. Radin argues that such attachments are best understood as a kind of fetish rather than as a genuine connection of personal identity. ${ }^{33}$ The nonsubjective nature of Radin's personal identity conception also enables her to explain the objectionability of policies like Dismantling the Bedridden. Although Ben's self-conception is unaffected by the removal of his organs (since he is unaware of these removals), from an objective perspective, society has taken resources (e.g., several of Ben's internal organs) that are (in Radin's view) important parts of Ben. Radin would thus be able to affirm that what is done to Ben is highly objectionable.

Radin's solution could be challenged by questioning her nonsubjective conception of personal identity or the distinction she draws between fetishes and genuine personal attachments. However, for the purpose of this article, I will take these features of Radin's theory as given. I wish to focus instead on three other problems with Radin's solution to the body-income puzzle.

First, Radin's claim that the taking of body parts constitutes a graver personal violation than the taking of labor income faces important objections that Radin does not consider. As Fabre argues, there are several reasons for doubting the importance that internal, nonessential organs such as a kidney have for our personal identity. For one thing, the consequences of a kidney's loss for individuals' life plans are fairly minor. ${ }^{34}$ For another, on purely psychological conceptions of the person, organs that are largely redundant (e.g., a second kidney) would not necessarily even count as part of the person. ${ }^{35}$ Finally, even if a kidney is part of the person, it is far less important to her personal identity than, say, a hand, be-

Radin, "Property and Personhood," 960.

Radin, "Property and Personhood," 966.

Radin, "Property and Personhood," 1005. Note that the term "personal violation" is mine.

Radin, “Property and Personhood," 968-70.

Radin, "Property and Personhood," 970.

Fabre, Whose Body Is It Anyway? 104-5.

For a discussion of this view of the person, see Fabre, Whose Body Is It Anyway? 12. 
cause a kidney is neither necessary for perceiving or interacting with the world nor does its loss affect how the person is seen by others. ${ }^{36}$

On the other side of the ledger, the personal connections between a person and her labor income are potentially stronger than Radin acknowledges. After all, Rich might have used the redistributed income to accomplish important life goals (e.g., pursuing a somewhat expensive but personally meaningful hobby). Moreover, the fact that Rich worked for his income-the fact that it is the result of his purposeful mental and physical activity-is a plausible source of substantial personal attachment to it. Thus, while Radin's claim that our body parts are more important than our labor income to our personal identity is not necessarily wrong, it is insufficiently defended.

A second problem with Radin's solution is the dearth of theoretical justifications she offers for granting personal identity fundamental importance in matters of distributive justice. Radin highlights several legal practices that can be plausibly explained by the connections between personal identity and entitlements to resources. ${ }^{37}$ But she offers almost no principled reasons for viewing personal identity (rather than welfare, autonomy, freedom, capabilities, self-respect, or other forms of advantage) as a key determinant of individuals' entitlements to resources. ${ }^{38}$

Third (and most importantly), Radin's solution cannot protect Healthy's kidney from redistribution. To see why, consider a variation of Healthy-Sick in which Sick will die in one year without Healthy's kidney. I submit that, even in this case, coercively redistributing Healthy's kidney to Sick is impermissible. Yet it is very difficult to see how Radin could argue that Healthy's kidney is more important to Healthy's personal identity than it is to Sick's. After all, Sick will cease to exist as a person without Healthy's kidney. Thus, Radin's claim that the strength of our entitlements to resources depends on these resources' importance to our personal identity cannot compellingly solve the body-income puzzle.

\section{RESPECT FOR THE SEPARATENESS OF PERSONS}

There is, however, an alternative body-specialness solution that can avoid the problems highlighted above. I will argue in the rest of this article that taking Healthy's kidney is more objectionable than taking Rich's income because it entails a greater disrespect for the separateness of persons.

Respect for the separateness of persons (RSP), as I understand it, is the idea that

36 Fabre, Whose Body Is It Anyway? 12.

37 Radin, "Property and Personhood," 991-1013.

38 For notable exceptions, see Radin, "Property and Personhood," 960, 968. 
each individual's life should be granted a certain primacy over considerations of the collective good. ${ }^{39}$ The collective good can be defined in a variety of ways (e.g., in terms of maximizing aggregate advantage, achieving equality of advantage, or ensuring sufficient advantage for every person). ${ }^{40}$ The unifying feature of collective-good conceptions is the proposition that greater good can sometimes be achieved by demanding sacrifices from one person for the sake of others. Respect for the separateness of persons serves as a bulwark against such demands.

RSP has been defended in a variety of ways. Warren Quinn, for example, offers the following justification for this value:

A person [should have] primary say over [his life]—not because such an arrangement best promotes overall human welfare, but because any arrangement that denied him that say would be a grave indignity. In giving him this authority, morality recognizes his existence as an individual with ends of his own — an independent being. Since that is what he is, he deserves this recognition. Were morality to withhold it, were it to allow us to kill or injure him whenever that would be collectively best, it would picture him not as a being in his own right but as a cell in the collective whole. $^{41}$

Other justifications for RSP differ from Quinn's in certain details. But they all appeal to the status of human beings as distinct individuals, each with his or her own ends. ${ }^{42}$

RSP can also be defended by highlighting its capacity to make sense of our strongly held judgments about particular cases. Consider, for example, the well-known thought experiment in which five individuals, each suffering from a different type of fatal organ failure, could be saved by killing one healthy person and redistributing her organs to the five. Although a variety of collectivist objectives (e.g., increasing aggregate welfare) would be advanced by killing the healthy person in this case, many have argued that doing so would unacceptably

There is a much weaker version of respect for the separateness of persons that only demands that we consider the distribution of welfare among different individuals. For a discussion of this weaker version and a defense of the version of RSP that I endorse, see Mack, "Non-Absolute Rights and Libertarian Taxation," sec. 2.

"Advantage" can be understood as a positive attribute or combination of attributes of a person or her circumstances that is relevant to distributive justice. For this usage, see Cohen, "On the Currency of Egalitarian Justice," 907, 916-17.

Quinn, “Actions, Intentions, and Consequences," 309-10.

See, for example, Zwolinski, “The Separateness of Persons and Liberal Theory," $153-54$. 
eny her the primacy she is due as a separate, independent being with her own mind, body, identity, projects, attachments, and life to lead. ${ }^{43}$

One way of cashing out this primacy is by seeing each person as having a special sphere of moral authority—a personal domain — constituted by a set of negative rights-domain rights - that protect the person from being sacrificed for others' sake. The healthy individual in the case above, for example, could be understood as having domain rights to her body_rights that protect her from having her organs seized, even when this is the only way of saving five others.

Evaluating RSP's capacity to solve the body-income puzzle will clearly require greater specificity regarding the nature of these rights. However, this value's potential for solving the body-income puzzle is not difficult to see. As the case above demonstrates, RSP can provide substantial protections to the body. Indeed, it can be understood as a justification for formal self-ownership. ${ }^{44}$ Moreover, unlike appeals to substantive self-ownership, welfarism, and identity-based claims to resources, RSP protects the body, not by appealing to the moral importance of a well-functioning body, but rather by setting limits on interference in individuals' bodily integrity. It can therefore protect healthy individuals from bodily takings without concomitantly strengthening the infirm's moral claims to the body parts they need for their bodily functioning. RSP-based solutions to the body-income puzzle therefore clearly merit further consideration.

\section{THE ADROIT CONCEPTION AND THE BODY-INCOME PUZZLE}

While the idea of a body-income-puzzle solution grounded in respect for the separateness of persons has considerable prima facie plausibility, it also faces important challenges. For one thing, both Fabre and Nozick endorse RSP while denying that a solution to the body-income puzzle exists. ${ }^{45}$ Thus, if a compelling RSP-based solution to this puzzle can be found, it will need to appeal to a conception of RSP different from the conceptions endorsed by Nozick and Fabre.

Competing conceptions of RSP disagree about two key issues. First, they disagree about the scope of the personal domain-the extent of the sphere of individual moral authority protected by RSP. Second, they disagree about the strength of individuals' domain rights - the weight individuals' claims against interference in their personal domain should be granted relative to competing moral considerations. I will argue in the rest of this article that there is a plau-

Timmons, Moral Theory, 144-45, 171. 
sible set of positions in these debates (different from the positions endorsed by Nozick and Fabre) that can offer a compelling solution to the body-income puzzle.

I call the conception of RSP that I will defend the adroit conception. "Adroit" is an acronym for "ample domain rights of inconstant tenacity." As the name suggests, this conception of RSP views each individual's personal domain as having extensive (i.e., "ample") scope. And it views domain rights as having a variable strength (i.e., "inconstant tenacity"). More specifically, the adroit conception endorses the following six commitments:

1. Each individual's personal domain extends to her entire body.

2. Each individual's personal domain extends to her labor income. ${ }^{46}$

3. The strength of domain rights ranges on a spectrum from very weak to very strong.

4. A key determinant of a domain right's strength is the magnitude of the personal violation associated with the right's infringement (i.e., the importance of the unwelcome consequences the right's infringement would have for the right-holder's personal identity).

5. At their weakest, an individual's domain rights can be permissibly infringed for the sake of satisfying even one individual's moderate claims to assistance.

6. At their strongest, an individual's domain rights have a strength that far outweighs the strength of another individual's claim to lifesaving assistance.

I leave the task of defending these commitments for section 6. My aim in this section is to argue that, if this conception of RSP is the right one, it can compellingly solve the body-income puzzle.

Before turning to this argument, a few caveats and clarifications are needed. First, as defined above, the adroit conception is admittedly not fully specified. A full specification would require a complete account of personal identity and a precise account of how domain-right strength varies with the magnitude of personal violations. I will not provide this type of full specification here. Instead, I will take Radin's (admittedly less-than-fully specified) conception of personal identity as given. I will also focus only on those comparisons of personal violations that are central to the body-income puzzle. And I will only argue that there is some plausible specification of the relationship between personal violations and the strength of domain rights (consistent with the six commitments above) that would enable the adroit conception to solve the body-income puzzle.

46 This is true under certain conditions that I will specify in section 6.2 below. 
Second, I will assume that the adroit conception of RSP is one principle in a pluralist theory of distributive justice that is also committed to fostering the collective good. And though I do not specify the relevant collective-good principles (e.g., whether they are aggregative, egalitarian, or sufficientarian), I will assume that these principles grant Poor and Sick strong pro tanto claims to assistance. With these clarifications in mind, I now turn to arguing that the adroit conception can indeed meet all five challenges posed by the body-income puzzle.

First, it can explain why taking Healthy's kidney is more objectionable than taking Rich's income. Like Radin's solution, it appeals to the graver personal violation associated with the kidney's taking. ${ }^{47}$ Given commitment 4 , this implies that Healthy's domain rights against the kidney's taking are stronger than Rich's domain rights against the taking of 20 percent of his labor income, and the kidney's taking is thus more objectionable. Admittedly, the claim that taking Healthy's kidney constitutes a graver personal violation than taking Rich's income is insufficiently defended by Radin. I therefore turn now to defending this claim more rigorously.

Consider first the personal violation associated with taking 20 percent of Rich's labor income. This violation is considerably less grave than it might first appear. For one thing, the life projects curtailed by a 20 percent tax are likely to have a circumscribed personal importance to Rich. After all, the tax is limited to a moderate amount of Rich's labor income, leaves Rich with a very substantial after-tax income with which to pursue his life plans, and allows Rich to choose which projects to surrender given this generous post-tax budget constraint. The tax is therefore unlikely to force Rich to surrender projects that are central to his personal identity.

The labor-based connections between Rich and the seized income are also weaker than they might initially appear. First (and most obviously), in taking only 20 percent of Rich's labor income, the state takes only a limited amount of the fruits of Rich's labor. Second, the fact that this wealth is not the immediate result of Rich's labor weakens Rich's personal connections to it. Compare, for example, a 20 percent tax on Rich's labor income to a proposal to redistribute 20 percent of the physical farming produce that Rich cultivated by hand. In the case of the physical produce, the long-term contact between Rich's body and the produce and the ways in which this produce has been shaped by Rich's choices could plausibly ground special personal attachments-attachments that do not the importance of personal violations by connecting them to respect for the separateness of persons. 
exist between Rich and the money he ultimately receives in exchange for this farming produce.

On the other side of the ledger, the taking of a kidney constitutes a personal violation that is far graver than skeptics like Fabre have recognized. First, the physical health risks associated with a kidney's removal (e.g., trauma and infection) are more serious than Fabre acknowledges. ${ }^{48}$ Second, there is a marked increase in the risk of mental health problems for those who surrender a kidney to others-a risk that Fabre does not consider. ${ }^{49}$

In addition, Fabre's distinctions between the taking of a kidney and the taking of external body parts are overstated. A person's interactions with the world and the way that she is seen by others are, after all, substantially impacted during the weeks-long postoperative recovery period. ${ }^{50}$ And the operation leaves an incision scar that serves as a visible reminder of the kidney's loss to the person and to those who can see that part of her body.

The taking of the kidney also constitutes a particularly grave personal violation because it entails cutting deeply into Healthy and removing a part of her. (This assumes that the person is constituted by her entire body, a claim I defend in section 6.1.) Moreover, what is taken from Healthy is not a single molecule, but rather an entire organ. And since kidneys do not regenerate, the loss is permanent and is for that reason more severe. In addition, the combination of irreversibility and substantiveness implies that, post-taking, Healthy might come to see herself (and might be characterized by others) as irredeemably "incomplete"-a substantial, unwelcome change to her personal identity. Indeed, in one study of those who sold a kidney, this is the way that many kidney vendors characterized themselves, even long after their kidney's loss. ${ }^{51}$

Another reason for the gravity of the personal violation associated with a kidney's taking is the connection between a person's purposeful choices and the condition of her kidney. Healthy may well have made decisions (e.g., in terms of what to ingest or what kind of activities to engage in) aimed at avoiding damaging her kidneys. Just as purposeful choices can ground personal connections between Rich and his labor income, so too the care that Healthy has taken in safeguarding her kidneys constitutes a significant source of personal attachment to them.

48 Wilkinson, "The Confiscation and Sale of Organs," 330-31.

49 In one study, psychiatric disorders went from a pre-donation rate of 2 percent to an alarming 31 percent. Switzer and Dew, "Psychosocial Issues in Living Organ Donation." The mental health problems caused by coerced organ takings may well be even greater. See Johns Hopkins Medicine, "What to Expect as a Living Donor." Moazam, Zaman, and Jafarey, "Conversations with Kidney Vendors in Pakistan," 34-35. 
A final reason for the strong personal connection between Healthy and her kidney is the important function that Healthy's kidney plays in the overall flourishing of Healthy's body. Healthy's kidney filters harmful (and potentially lethal) waste from her blood. This makes Healthy's kidney far more personally important than, say, Healthy's appendix, which serves no discernable function in Healthy's body.

An obvious rejoinder is that Healthy's kidney is unimportant for the functioning of Healthy's body because the other kidney can take over the function of the removed kidney. However, this rejoinder underestimates the importance of Healthy's kidney in three ways. First, a second kidney is not completely redundant. One kidney is not quite as good at purifying the blood as two. ${ }^{52}$ Second, each kidney plays an important backup function in case the other kidney fails. Third (and most importantly), even if each kidney was perfectly reliable and fully capable of doing the purification work of two kidneys, it is a mistake to evaluate the value of a contributing factor to a cooperative enterprise using a "marginal product" approach (i.e., by only considering the consequences of the contributing factor's absence given that all other contributing factors are present).

To see why, consider a team of ten individuals who jointly create a product worth $\$ 10$ million. The team decides to split the proceeds of the product's sale according to the importance of each team member's contribution, judged by what would have happened had each been absent. As it turns out, though, the consequences of any one team member's absence would have been fairly minor $-\$ 100,000$ loss from the overall value of the project (since the other team members would have picked up the slack). According to this way of estimating each team member's value, then, the sum of the value of the ten team members is only $\$ 1$ million (rather than the $\$ 10$ million value of the project).

As this example suggests (and as economists have long recognized), it is implausible to use a factor's "marginal product" to determine its value to some overall cooperative enterprise because the sum of the marginal products of the cooperating factors will often either over-exhaust or (as in the case above) under-exhaust the total value of the enterprise. ${ }^{53}$ It is thus a mistake to think about a kidney's value to the body's flourishing by only evaluating what would happen to the body if that kidney was not there. The kidney is part of a two-kidney team with enormous importance to the body's flourishing. On a variety of ways of estimating the value of contributing factors to a cooperative enterprise that are more plausible than the marginal product approach, Healthy's kidney can be 
judged to have considerable importance to her bodily flourishing and therefore to her personal identity. ${ }^{54}$

Thus, while taking 20 percent of Rich's labor income may well constitute the greater welfare loss, taking Healthy's kidney can reasonably be seen as the graver personal violation. If so, then the adroit conception would grant Healthy's domain rights against the taking of her kidney greater strength than it grants to Rich's domain rights against the taking of 20 percent of his labor income. The adroit conception can therefore judge the kidney's taking to be more objectionable.

The adroit conception can also protect Healthy's kidney from redistribution, even in the face of Sick's pressing claims to assistance. Remember that the adroit conception grants the strongest individual domain rights a strength that far outweighs the strength of even another individual's claims to lifesaving assistance. And while Healthy's domain rights against the taking of her kidney are certainly not the strongest possible, I argued above that they are quite strong. There is thus a plausible specification of the relationship between domain-right strength and personal violations (consistent with commitment 6) that would protect Healthy's kidney from redistribution, even if Sick needs Healthy's kidney to survive.

Yet the adroit conception does not grant the body absolute protection. It can, for example, condone the taking in Drop of Blood to Save a Billion. Remember that the adroit conception holds that the weakest domain rights can be permissibly infringed in the face of even moderate claims to assistance (commitment 5). And while Adam's domain rights against the taking of a single drop of blood are certainly not the weakest possible, they are clearly substantially weaker than Healthy's rights against the taking of her kidney. A drop of blood is, after all, an easily replaced, relatively insignificant part of Adam's body. Moreover (and more importantly), a billion individuals' claims to lifesaving assistance are immensely strong in aggregate. The adroit conception could thus straightforwardly permit the taking of one drop of Adam's blood in this case.

The adroit conception can also justify redistributing 20 percent of Rich's labor income to Poor. While Rich's domain rights against the taking of 20 percent of his labor income are certainly not the weakest possible, I argued above that they are relatively weak (at least compared to Healthy's rights to her kidney). Since Poor's disadvantage-based claims to financial assistance are ex hyptothesi strong, and since the adroit conception holds that the weakest domain rights can

54 A prominent solution to this problem, the Shapley value (see Young, "Individual Contribution and Just Compensation"), calculates the average marginal product of the factors, where the average is taken over all possible orderings of the cooperating factors. For any orderings of body parts in which kidney 2 is not already present, kidney 1 would obviously have a very high value. Thus, a kidney's Shapley value would be quite high, despite the other kidney's capacity to make up for its absence. 
be justifiably infringed for the sake of satisfying even moderate claims to assistance, there is a plausible specification of the relationship between domain-right strength and the magnitude of personal violations that would permit redistributing 20 percent of Rich's labor income to Poor.

Finally, the adroit conception can place attractive limits on labor-income taxation. Consider again the heavy two-kidney-based taxes proposed earlier. Unlike the 20 percent redistributive tax imposed on Rich, the heavy two-kidney-based taxes infringe on Healthy's rights to all or nearly all of her labor income. Since the loss of this income would require Healthy to surrender nearly all of her key life projects, these taxes constitute a very grave personal violation. And since the adroit conception holds that the strongest individual domain rights can easily outweigh even lifesaving claims to assistance, it can justify rejecting heavy twokidney-based taxation, even if such taxation would save Sick's life. Thus, as part of a pluralist theory of justice that is also committed to the collective good, the adroit conception of RSP can meet all five challenges posed by the body-income puzzle.

\section{DEFENDING THE ADROIT CONCEPTION}

Some readers may dismiss the adroit conception of respect for the separateness of persons as ad hoc-specifically designed to solve the body-income puzzle. Others may argue that, whatever its merits in solving this particular puzzle, it is an implausible conception of RSP. However, I will argue in this section that each of the adroit conception's six commitments are compelling, independently of their contributions to solving the body-income puzzle.

\subsection{The Entire Body and the Personal Domain}

Consider first the adroit conception's commitment to the inclusion of the entire body in an individual's personal domain. This commitment has considerable prima facie appeal. After all, it seems reasonable to hold that respect for the separateness of persons should at least protect persons from being sacrificed for the collective good. And the idea that the person is constituted by her entire body has been defended by a variety of scholars. ${ }^{55}$ It also has considerable intuitive plausibility. If you were asked to divide the universe into two parts, you and notyou, most readers would, I think, make the cut at the boundary of their body.

However, some might object that "a person" is much better understood not in terms of a physical body but rather in terms of purely mental capacities such as being self-conscious, being aware of one's identity and its continued existence

55 Radin, "Property and Personhood," 965-66. See also Jensen and Moran, The Phenomenology of Embodied Subjectivity. 
over time, or having the capacity for moral and rational agency. ${ }^{56}$ On this understanding of "the person," an individual's personal domain might be seen as extending only to what Jeff McMahan calls "the embodied mind" (i.e., only to those parts of the body needed to support the mental activities constitutive of personhood). ${ }^{57}$

Proponents of this conception of the person often defend it by appealing to the elements of a person necessary for remaining the same person over time. They compellingly point out that a person can lose large portions of her body (or, in science fiction thought experiments, even her entire body) while still fundamentally remaining the same person.

However, it is a mistake to define what constitutes "a person" by considering the elements that are necessary to ensure that a particular individual remains the same person over time. This intertemporal identity question inquires after what is essential to a particular individual's identity as a specific person. This is different from the question of what constitutes the person. For example, a person whose hand is chopped off is still fundamentally the same person. But the attack nevertheless constitutes an assault on her person. Her hand is part of her person, even if it is not essential to her identity as the particular person that she is. Thus, even if purely psychological answers to the question of what it takes to remain the same person over time are right, this does not challenge the view that "a person" should be defined in ways that include her nonessential body parts. It therefore does not challenge the adroit conception's inclusion of the entire body in the personal domain.

\subsection{Labor Income and the Personal Domain}

The adroit conception's inclusion of labor income in the laborer's personal domain also has considerable intuitive appeal. There is, after all, a widespread judgment that individuals' pretax income is (in some morally substantive sense) theirs. ${ }^{58}$ British Prime Minister David Cameron appealed to this judgment when he told his supporters, "I know it's your money. I know you want some of it back.... But we will only cut taxes once we've made government live within its means." ${ }^{\text {Bg }}$ Accepting that individuals' labor income falls within their personal domains can make sense of this widespread judgment.

56 For a discussion, see Fabre, Whose Body Is It Anyway? 12.

57 McMahan, The Ethics of Killing, 66-94.

58 For another example and a brief discussion of the widespread nature of this judgment, see Murphy and Nagel, The Myth of Ownership, 35-36. Murphy and Nagel go on to argue that this judgment is misguided. I consider some of their arguments below. 
The inclusion of labor income in individuals' personal domain also has considerable scholarly support, especially among orthodox libertarians (e.g., Nozick). ${ }^{60}$ The libertarian defense of this position is complex, and I cannot rehearse it fully here. But the basic idea is that if RSP protects the body it should also protect the fruits of the body's activity (e.g., labor income).

This traditional libertarian argument can admittedly be challenged by appealing to labor income's reliance on natural and social inputs. I already highlighted several general problems with this challenge in section 2. Here I wish to further respond to this challenge by considering each of the distinctions made between body-part ownership and labor-income ownership and arguing that none of them justify excluding labor income from the laborer's personal domain.

Consider first labor income's reliance on natural inputs. If an individual's personal domain does not extend to any part of the natural world, then it may be reasonable to exclude wealth generated using her body and the natural world from her personal domain. ${ }^{61}$

However, wholly excluding rights to the natural world from individuals' personal domains is implausible. To see why, consider the following policy:

Air Rights for a Kidney: Healthy is granted full property rights to her body. However, her rights to breathe air are made conditional on her transferring one of her kidneys to Sick. Faced with this air-property-rights regime, Healthy agrees to transfer one of her kidneys to Sick.

I submit that Air Rights for a Kidney violates RSP. It imposes an intuitively unacceptable sacrifice on Healthy for the sake of the collective good. Yet we cannot explain why this is so if we view each individual's personal domain as extending no further than the boundary of her body. On the other hand, we can straightforwardly explain why Air Rights for a Kidney violates RSP if we view Healthy's rights to the air she needs to breathe as falling within her personal domain.

Determining precisely how far into the natural world each individual's personal domain extends is beyond the scope of this article. However, if rights to some of the world's plentiful air fall within Healthy's personal domain, it seems plausible that rights to some arable land could also fall within Rich's personal domain, at least when this land is plentiful. If Rich's body and farmland fall within his personal domain, I take it to be uncontroversial that the wealth Rich gener-

60 Nozick, Anarchy, State, and Utopia, 169. See also Wheeler, "Natural Property Rights as Body Rights," 172-79. Although Wheeler does not explicitly appeal to RSP, he argues that individuals have the same type of rights to their income as they do to their bodies.

61 For a conception of RSP that limits the personal domain to the body, see Dworkin, "Comment on Narveson," $38-39$. 
ates through the use of these inputs and no others (i.e., in a state of autarky) also falls within his personal domain.

Yet some may nevertheless advocate excluding Rich's labor income from his personal domain by appealing to this income's reliance on transactions. One reason suggested by John Christman's work for doing so is that particular transactions are the result of social facts (e.g., the particular distribution of competitors in the economy) for which the transacting agent is not responsible. ${ }^{62}$

However, note that Rich is not responsible for many of the factors that affect his wealth in a state of autarky (e.g., the weather, the lack of insects in the area). $\mathrm{He}$ is also not responsible for many features of his body (e.g., being born with two healthy kidneys). If Rich's body and the wealth he produces in a state of autarky nevertheless fall within his personal domain, it is unclear why Rich's lack of responsibility for, say, the distribution of competitors justifies excluding the fruits of his transactions from his personal domain.

Another objection to including the fruits of transactions in the personal domain (also suggested by Christman's work) is that transactions require a certain type of control over others. ${ }^{63}$ And it admittedly seems implausible to include resources that are based on "other-control" in the sphere of moral authority protected by respect for the separateness of persons.

In response, I do not deny that some transactions are based on control over others. If Rich enslaved others in order to earn his farming wealth, this wealth would clearly be based on other-control. Transactions based on fraud or exploitation could also plausibly be described as grounded in a certain type of control over others. I freely concede that the fruits of these transactions should be excluded from Rich's personal domain.

However, when Rich's transactions are just-non-fraudulent, non-exploitative, and uncoerced on all sides-it is difficult to see how the resulting wealth can be plausibly described as based on control over others. It is thus difficult to see why the dependence of Rich's wealth on just transactions would warrant excluding the resulting wealth from Rich's personal domain.

One final objection to labor income's inclusion in the personal domain appeals to its reliance on government-provided goods. As Murphy and Nagel point out, without goods like the monetary system, individuals (e.g., Rich) would not have any income whatsoever. Murphy and Nagel conclude that it is thus incoherent to grant Rich any type of rights to his pretax labor income. ${ }^{64}$

However, this argument is unconvincing. To see why, consider a case in

62 Christman, "Self-Ownership, Equality, and the Structure of Property Rights," 31.

63 Christman, "Self-Ownership, Equality, and the Structure of Property Rights," 34.

64 Murphy and Nagel, The Myth of Ownership, 32. 
which Rich needs Johnny's seeds to produce farming output. In this case, Rich's farming produce would not exist without Johnny's seeds. And we may not even know what Rich's income would be in the absence of Johnny's seeds. Yet it does not follow that it is logically incoherent to grant Rich domain rights to a substantial portion of his farming produce. Rich could, for example, offer Johnny a percentage of his ultimate farming produce in exchange for using the seeds. As long as Rich's agreement with Johnny is just, Rich could perfectly coherently have domain rights to his post-seed-payment farming produce.

Now consider the monetary system. There is no denying that Rich's income fundamentally depends on this system. However, just as Rich can coherently have domain rights to his post-seed-payment farming produce, so too there is nothing incoherent about granting Rich domain rights to the labor income that remains after Rich has paid his just share of the costs of the monetary system (and any other government-provided inputs he has used in generating his wealth).

The debate over individuals' rights to their labor income is admittedly complex, and I do not claim to have definitively settled it here. However, when a person's wealth is the result of the use of her body, her just share of the natural world, and just transactions with others, and when she has justly paid for the government-provided goods she has used, I see no compelling reasons for excluding the remaining labor income from her personal domain.

\subsection{The Variable Strength of Domain Rights}

Consider next the adroit conception's commitment to the variability of domain-right strength. This position enjoys substantial scholarly support. ${ }^{65}$ It is also intuitively attractive. Imagine that, rather than a billion lives being at stake in Drop of Blood to Save a Billion, the number of lives threatened by the epidemic is $X$. Next, imagine that saving $X$ lives requires removing and studying one of the following parts of Adam's body:

1. One drop of Adam's blood,

2. one of Adam's kidneys, or

3. large parts of the frontal lobe of Adam's brain.

I submit that the number of individuals $(X)$ whose lives must be at stake to make the taking permissible varies with the type of taking. If so, and if Adam's entire body falls within his personal domain, this suggests that domain rights are indeed best understood as having variable strength.

65 See, for example, Quinn, "Actions, Intentions, and Consequences," 310. For another defense of the variable strength of rights against bodily interference, see Thomson, The Realm of Rights, 154-55. 
However, this position is subject to two key challenges. First, some might reject any differences in domain-right strength. Samuel Wheeler, for example, argues that rights have no underlying dimension. A right is either infringed or it is not. ${ }^{66}$ Thus, in Wheeler's view, if I have rights to some ample food supply that I have justly acquired, and I have a right to my body, then the taking of some of my food supply to feed the starving is morally "on a par" with the taking of some of my flesh to feed the starving. ${ }^{67}$

However, Wheeler's argument is unconvincing. It may well be that right infringements do not admit degrees (i.e., a right is infringed or it is not, it cannot be partially infringed). However, it does not follow that what it takes to justify the infringement of a right must be the same for all rights (i.e., that all rights have the same strength). Thus, we cannot conclude from the existence of rights to my food supply and rights to my flesh that their takings are morally on a par. It is perfectly possible (and indeed intuitively plausible) that my rights to my flesh are stronger than my rights to (every portion of) my ample food supply. If so, then certain competing considerations (e.g., others' starvation) might make the taking of some of my ample food supply, but not my flesh, permissible.

A more powerful challenge to the adroit conception's position is posed by Fabre. While the adroit conception views domain-right strength as a spectrum, Fabre endorses a single right-strength threshold. A person's right against "minor" domain interference has no strength while a person's right against "more than minor" domain interference has absolute or near-absolute strength (where the threshold between "minor" and "more than minor" lies at the level of interference that substantially threatens a person's ability to lead a minimally flourishing life) ${ }^{68}$

Fabre defends her position by claiming that a passerby has a ten-second duty of justice to physically help her up if she slips on an icy pavement. ${ }^{69}$ This intuitively plausible duty of rescue can be straightforwardly explained by accepting Fabre's claim that individuals' rights against sufficiently minor interference with their personal domain have no strength.

However, while Fabre's example does challenge absolutist conceptions of RSP, it does not pose a serious challenge to the adroit conception. Given the very limited nature of what is required of the passerby, the adroit conception need not view the passerby's domain rights against this duty of rescue as having a great deal of strength. Thus, assuming that Fabre's plight of being sprawled on the icy pavement is sufficiently grave (e.g., she cannot get up herself, it is very

66 Wheeler, "Natural Property Rights as Body Rights," 182.

67 Wheeler, "Natural Property Rights as Body Rights," 184.

68 Fabre, Whose Body Is It Anyway? 112-118.

69 Fabre, Whose Body Is It Anyway? 112. 
cold outside, and there is no one else around who will help her up), the adroit conception could affirm the passerby's ten-second duty of justice to help Fabre up. In this case, then, both Fabre's view of domain-right strength and the adroit conception's view have plausible implications.

However, the greater plausibility of the adroit conception's position becomes apparent when we consider domain rights that lie near each other but on different sides of Fabre's threshold. Consider, for example, the following two cases:

Major Sacrifice of One for Many: Andrea would make for an exquisitely talented surgeon, saving the lives of one hundred people over the course of her career who would otherwise die. However, Andrea dislikes surgery and prefers to be a gardener. The government forces Andrea (on pain of jail) to become a surgeon.

Moderate Sacrifice of Many for One: Betsy is struck by a fatal disease. Finding a cure requires testing millions of different chemical combinations. The government forces all one million of society's eighteen-year-olds (on pain of jail) to spend one year after secondary school testing chemical combinations (or supporting this effort administratively) for minimum wage, with waivers for anyone whose ability to lead a minimally flourishing life would be jeopardized by this requirement.

I submit that both Major Sacrifice of One for Many and Moderate Sacrifice of Many for One are impermissible. However, while Fabre can reject Major Sacrifice of One for Many because the sacrifice asked of Andrea would undermine her ability to lead a minimally flourishing life, Fabre's account of domain-right strength commits her to endorsing Moderate Sacrifice of Many for One. ${ }^{70}$ After all, Betsy has weighty claims to assistance. And the loss of a year of occupational choice for the one million eighteen-year-olds does not jeopardize their ability to lead a minimally flourishing life. ${ }^{71}$

However, what is most implausible about Fabre's view is not its endorsement of Moderate Sacrifice of Many for One. Rather, it is the implication that this case is not even a moral dilemma. A year of occupational choice for one million individuals - an opportunity for them to take important, often foundational steps

70 Fabre, Whose Body Is It Anyway? 55-56. This is so at least as long as no one else's capacity to lead a minimally flourishing life can be fostered by the million 18 -year-olds' sacrifice.

71 Fabre endorses a mandatory year of civilian service for the sake of the disadvantaged. See Fabre, Whose Body Is It Anyway? ch. 3. Note that Moderate Sacrifice of Many for One is substantially more intuitively unappealing because the relevant sacrifice is made for the sake of only one person (though this does not change the implications of Fabre's theory). 
toward fulfillment of key life projects — is granted no protection at all by Fabre's conception of RSP. This seems very difficult to accept.

\subsection{Personal Violations and Domain-Right Strength}

Consider next the adroit conception's view of the magnitude of personal violation as the key determinant of domain-right strength. This position has considerable scholarly support. ${ }^{72}$ It also has substantial theoretical appeal. Respect for the separateness of persons is, after all, fundamentally concerned with safeguarding each person's individuality in the face of collectivist demands. It therefore seems reasonable to see the severity of the violations of this value as dependent on how close coerced sacrifices come to the core of who the individual is.

This position can also make sense of our judgments regarding the relative objectionability of different types of domain interference. As Quinn argues, it is because of the fundamental connections between our minds and who we are that our rights against being lobotomized for the sake of the collective good are far stronger than our rights against other types of bodily encroachments. ${ }^{73}$

Consider also the case of Hairy-Bald introduced in section 2. I suggested that the objectionability of redistributing Hairy's detached hair is much more akin to the objectionability of redistributing Rich's labor income than to the objectionability of redistributing Healthy's kidney. And the adroit conception can straightforwardly explain why this is so. Hairy admittedly has somewhat greater personal connections to his detached hair than Rich has to his labor income because the hair used to be a part of Hairy. However, taking Hairy's detached hair does not impose health risks on Hairy, does not require cutting deep into Hairy, and does not require taking any part of Hairy (let alone a substantial, functional part). The adroit conception can thus affirm that taking 20 percent of Hairy's detached hair is only modestly more objectionable than taking 20 percent Rich's labor income.

However, the adroit conception's view of the determinant of domain-right strength is not the only plausible one. Fabre holds that the strength of a domain right is based on the effects its infringement would have on the right-holder's ability to lead a flourishing life-a complex capacity that depends on a variety of factors, including one's self-respect; ability to satisfy current plans, projects, goals, and interests; and ability to reflect and choose one's goals and actions. ${ }^{74}$ Like the adroit conception's position, Fabre's view can explain the robustness of

74 Fabre, Whose Body Is It Anyway? 28-29, 113-18. 
our rights against being lobotomized and the similarity of Hairy's detached hair to Rich's labor income in terms of redistribution objectionability.

However, Fabre's view has intuitively implausible implications in other cases. Consider, for example, the following policy:

Secret Sexual Access: The government secretly grants the sexually deprived - those unable to find willing sexual partners, even for moneyaccess to the bodies of attractive individuals who have been anesthetized for medical operations. Foolproof protection from disease and pregnancy are used as well as cleaning measures that ensure that the consequences of the sexual activity will be unnoticed by the patients. The patients' faces are also covered so that their identity is kept secret from the sexually deprived.

Though Fabre recognizes that the sexually deprived have weighty claims to assistance, and though she generally demands a great deal from the advantaged, even she balks at demanding that individuals' bodies be made available to the sexually deprived. ${ }^{75}$ However, none of the negative effects on the ability to lead a flourishing life that Fabre appeals to in order to reject the sexually deprived's demands for access to others' bodies are relevant in Secret Sexual Access. Secret Sexual Access poses no physical or psychological risks for the patients nor has any effect on their subjective welfare. This policy would also have no consequences for how the patients see their bodies or sex. Fabre's view of the determinant of domain-right strength thus implies that this policy is, at worst, mildly objectionable. ${ }^{76}$ Yet I take it that Secret Sexual Access is in fact highly objectionable.

This objectionability can be easily explained by the adroit conception. As many theorists have compellingly argued, our sexual integrity is intimately connected with our personal identity. ${ }^{77}$ Given that the adroit conception endorses a nonsubjective account of personal identity, what is done to the patients in Secret Sexual Access can straightforwardly be classified as a very grave personal violation and can thus be judged by the adroit conception to be highly objectionable, despite the benefits for the sexually deprived. the ability to lead a minimally flourishing life, see Fabre, Whose Body Is It Anyway? 118-23. Fabre could appeal to individuals' non-experientialist interest in physical integrity. Yet elsewhere, Fabre argues that such non-experientialist interests do not have a great deal of importance for our ability to lead a flourishing life. See Fabre, Whose Body Is It Anyway? 87-88. See Archard, “The Wrong of Rape." 


\subsection{The Weakest Domain Rights and Moderate Claims to Assistance}

Consider next the adroit conception's endorsement of the permissibility of infringing on the weakest domain rights for the sake of meeting others' moderate claims to assistance. To see this commitment's intuitive appeal, assume it is possible to cure Poor's serious, permanent limp by taking a single cent of Rich's $\$ 100,000$ income. Assume also that the redistribution process is costless for all involved. I submit that taking a single cent from Rich is permissible in this case. If so, this suggests that very weak domain rights can indeed be permissibly infringed for the sake of satisfying even moderate claims to assistance.

One challenge to this position could be pressed by orthodox libertarians, who sometimes insist that domain rights are absolute. ${ }^{78}$ However, the problems with this orthodox libertarian view are by now familiar. Insisting on the absoluteness of domain rights would not only require the state to forbear from taking a single cent of Rich's income to cure Poor's limp. It would also require near-complete paralysis on the part of humanity. ${ }^{79}$ After all, nearly all actions taken in a social setting (e.g., walking to the store) pose some risk of infringing on someone else's body. Thus, insisting on absolute domain rights would imply that almost no action taken in a social setting is permissible, regardless of its benefits. Given this patently implausible implication, it is perhaps unsurprising that, despite occasional insistence on domain-right absoluteness, it is difficult to find any libertarian who consistently endorses such a radical position. ${ }^{80}$

A more powerful challenge to the adroit conception's position is posed by Eric Mack. Mack does not deny that sufficiently weak domain rights can sometimes be infringed for the sake of alleviating severe disadvantage. But he denies that the right-holder is ever under an obligation to facilitate the infringement of her domain rights. ${ }^{81}$ Thus, even if Poor can permissibly seize a cent from Rich to cure her limp, Mack denies that Rich is obligated to facilitate this taking. If Mack is right, then the adroit conception's position on the infrangibility of domain rights would be insufficient to justify income taxation (which coercively demands taxpayer cooperation) and would thus be insufficient to solve the body-income puzzle. ${ }^{82}$

Mack's defense of his position is complex, and I cannot rehearse it fully here.

78 Rothbard, The Ethics of Liberty, 60.

79 Mack, "Nozickian Arguments for the More-than-Minimal State," 112-13.

80 For example, Rothbard concedes that air pollution is permissible as long as any damages caused are paid for ("Law, Property Rights, and Air Pollution," 77). Yet absolute rights to one's body would imply that explicit consent from those affected is required.

81 Mack, "Non-Absolute Rights and Libertarian Taxation," 120.

82 There is a justification for a kind of tax system that can follow from Mack's premises, though 
But his basic point is that a theory that grants others a right to take Rich's income and also imposes an obligation on Rich to turn over his income to others makes Rich's rights to the redistributed income effectively meaningless. ${ }^{83}$ Mack also suggests that such a theory would impose demands on those in a position to assist others that are intuitively overdemanding. ${ }^{84}$

However, Mack's claim that obligations to facilitate the infringement of one's domain rights are overdemanding is unconvincing. To see why, it is first important to clarify a potential point of confusion about the demands the adroit conception places on those in a position to assist others. Poor's serious limp being sufficiently serious to justify infringing on a cent of Rich's income does not commit the adroit conception to endorsing Rich's coercively enforceable obligation to transfer a cent to Poor. To justify such an obligation, Poor's plight would have to be sufficiently serious to justify infringing on Rich's right to the cent and all of the domain rights associated with Rich's facilitation of the cent's transfer. So, if Rich must physically deliver the cent to Poor at a faraway location, the adroit conception could well affirm, in line with Mack, that Rich is not obligated to facilitate the cent's transfer.

However, consider now a case in which Rich can transfer the cent with a few keyboard strokes and the cent is needed to save the lives of one thousand of Rich's compatriots. I submit that coercively requiring Rich to facilitate the infringement of his domain rights to the cent is not overdemanding in this case. Yet, while the adroit conception can straightforwardly endorse this faciliation obligation, Mack is committed to denying it.

Mack's claim that obligations to facilitate the infringement of one's domain rights renders these rights meaningless is also unconvincing. For one thing, accepting that taxpayers have (infringed) rights to the wealth they are obligated to transfer to the state affects our proper attitude toward taxation. It implies that those who surrender their labor income for the sake of the indigent properly merit appreciation for their sacrifice in ways that, say, individuals who are paying back a government loan do not.

Recognizing taxpayers' rights to the wealth they transfer to the state can also

the argument for it is complicated. See Mack, "Non-Absolute Rights and Libertarian Taxation," $138-41$.

83 Mack, "Non-Absolute Rights and Libertarian Taxation," 121-22.

84 Mack appeals to the judgment that it would be overdemanding to coercively require a cabin owner to communicate the location of the cabin's hidden key to a faultlessly freezing hiker who will die without access to the cabin ("Non-Absolute Rights and Libertarian Taxation," 120-21). Though I do not share this judgment, I concede that the rejection of the cabin owner's obligation to facilitate the infringement of his domain rights is plausible in this particular case. 
have practical distributive consequences. Imagine, for example, that the state suddenly obtains a large windfall of wealth. Recognizing taxpayers' pro tanto rights to the wealth they have previously transferred to the state would imply that there is a case not only for using this windfall to reduce future taxes but also for using some of it to compensate past taxpayers for previous right-infringements. A theory that did not recognize taxpayers' infringed rights to their previously transferred wealth would not have this implication.

Third (and most importantly), recognizing taxpayers' rights to the wealth they turn over to the state has key implications for the strength of their claims against taxation. A theory that did not recognize Rich's rights to his pre-redistributive-tax income would have great difficulty explaining why we should give special weight to the income's importance for Rich's personal projects when deciding how much of Rich's wealth to take.

Thus, there is nothing implausible about accepting that the advantaged sometimes have coercively enforceable obligations to facilitate the infringement of their own domain rights (e.g., by transferring some of their labor income to the state). If so, then accepting the infrangibility of weak domain rights for the sake of meeting moderate claims of assistance could justify substantial levels of labor-income taxation.

\subsection{The Strongest Individual Domain Rights and Lifesaving Assistance}

Finally, consider the adroit conception's commitment to viewing the strongest of an individual's domain rights as far weightier than even another person's claims to lifesaving assistance. This position's intuitive appeal can be illustrated by the example I used to introduce RSP - the prohibition on killing one person to use her organs to save five others. However, for readers unmoved by this well-known case, let me offer another example from the social sphere:

Suicidal's Marriage Proposal: A woman is offered marriage. Although she likes the suitor and enjoys their physical relationship, she takes marriage seriously and does not wish to be attached to him in this way. However, the woman has recently learned that the suitor will commit suicide (due to mental illness) unless she marries him.

Despite this being a matter of life and death for the suitor, I submit that the woman does not act unjustly by rejecting his proposal. This can be straightforwardly explained by accepting that the strongest of an individual's domain rights can easily outweigh even others' claims to lifesaving assistance.

Some readers might object that I have mischaracterized this moral situation. They might argue that, though justice does require the woman to marry the 
suicidal suitor, the woman has a personal prerogative (grounded in the special weight she is entitled to give her own plans and commitments) to ignore the requirements of justice when they ask too much of her in certain ways. ${ }^{85}$ Appealing to personal prerogatives admittedly makes it possible to give domain rights little or even no weight while also rejecting the woman's obligation to marry the suicidal.

However, as Mack compellingly argues, appeals to prerogatives cannot plausibly obviate the need for accepting RSP as a principle of justice. ${ }^{86}$ If the only reason the woman lacks an obligation to marry the suitor is her personal prerogative to ignore the requirements of justice, then it would be permissible for an omniscient, disinterested third party to coerce the woman into marrying the suitor. After all, this third party would have no reason to favor the woman's personal commitments and interest in controlling whom she marries over the suitor's life. Yet I take it that this coercion would be patently impermissible. If so, then we cannot plausibly appeal to personal prerogatives to avoid endorsing (as part of our theory of justice) a commitment to RSP that protects the most intimate and personally important parts of a person's life from others' claims to assistance, even when another person's life is on the line.

\section{A SOLUTION IN ALL CASES?}

I have argued in the previous two sections that the adroit conception of respect for the separateness of persons (as part of a pluralist theory of distributive justice also concerned with fostering the collective good) is both compelling and capable of solving the body-income puzzle. However, this solution is admittedly subject to an important objection that I wish to consider in this final section. Namely, it does not seem to work in all cases.

To see the problem, consider the following variations of Rich-Poor and SickHealthy:

Income for Religious Pilgrimage: Rich wishes to go on a pilgrimage required by his religion. However, the pilgrimage is sufficiently expensive so that a 20 percent redistributive tax would force Rich to abandon this critical life project. ${ }^{87}$

Kidney-Cell Teleportation: Sick can grow a new kidney as long as a single

85 Scheffler, Rejection of Consequentialism. See also Fabre, Whose Body Is It Anyway? 34.

86 Mack, "Prerogatives, Restrictions, and Rights."

87 For a real-world example, see Wajihuddin, "Pilgrims Protest 9\% Service Tax on Haj, Likely to Move Supreme Court." 
cell from Healthy's kidney is implanted in his body. A technology is available that can painlessly and noninvasively teleport a single kidney cell from Healthy's body to Sick's.

In this pair of cases, the adroit conception seems committed to offering greater protections to Rich's labor income than to Healthy's body part because the income's taking seems to constitute the greater personal violation. After all, the income's taking deprives Rich of the ability to pursue a project that is central to his life plans and self-conception. The taking of Healthy's kidney cell, on the other hand, is painless, riskless, and noninvasive and takes a miniscule, inconsequential, and quickly regenerating part of Healthy's body. This pair of cases thus demonstrates that the adroit conception cannot in fact solve the body-income puzzle laid out in section 1 .

In response, I freely concede that the adroit conception would grant greater protection to Rich's labor income than to Healthy's body part in this pair of cases. However, I deny that this implies that the adroit conception fails to solve the body-income puzzle. The body-income puzzle (on my understanding of it) does not require granting nonessential body parts greater protection than labor income in all possible worlds. Rather, it implicitly asks us to explain the greater protection that should be granted to body parts in the typical circumstances that confront policymakers. Income for Religious Pilgrimage and Kidney-Cell Teleportation are highly atypical cases in which the ordinary ordering of the protections offered to labor income and body parts should, I submit, be reversed. The adroit conception's capacity to explain why this is so is thus a strength rather than a weakness.

\section{CONCLUSION}

I began this article with a seemingly simple question. Why should society reject the redistribution of nonessential body parts while condoning the redistribution of labor income? I argued that answers to this question that reject individuals' ownership of labor income, that appeal to the greater welfare loss associated with bodily takings, and that appeal to general personal-identity-based entitlements to resources are unconvincing.

I defended instead a solution to this puzzle grounded in a novel conception of respect for the separateness of persons. This conception does not deny that individuals have rights to their labor income. Instead, it recognizes that seizing resources that lie closer to the core of who we are entails a greater disrespect for our separateness as persons. Since bodily resources such as our kidneys are 
substantial, non-regenerating parts of us-parts that we have cared for and that play an important role in our bodies' functioning - their taking comes closer to the core of who we are than does the taking of a moderate portion of our labor income, at least when we are left economically well-off. Respect for the separateness of persons, rightly understood, can therefore explain why the weighty claims of the disadvantaged to assistance can justify the redistribution of considerable amounts of labor income but are generally insufficiently strong to justify the redistribution of substantial portions of the human body. ${ }^{88}$

London School of Economics j.m.mazor@lse.ac.uk

\section{REFERENCES}

Archard, David. "The Wrong of Rape." Philosophical Quarterly 57, no. 228 (July 2007): 374-93.

Becker, Gary, and Julio Jorge Elias. "Introducing Incentives in the Market for Live and Cadaveric Organ Donations." Journal of Economic Perspectives 21, no. 3 (Summer 2007): 3-24.

Cameron, David. "David Cameron's Speech in Full." The Guardian, October 1, 2008. https://www.theguardian.com/politics/2008/oct/o1/davidcameron .toryconference1.

Christman, John. "Self-Ownership, Equality, and the Structure of Property Rights." Political Theory 19, no. 1 (February 1991): 28-46.

Cohen, G. A. "On the Currency of Egalitarian Justice." Ethics 99, no. 4 (July 1989): 906-44.

Dworkin, Ronald. "Comment on Narveson: In Defense of Equality." Social Philosophy and Policy 1, no. 1 (Autumn 1983): 24-40.

Eyal, Nir. "Is the Body Special?" Review of Whose Body Is It Anyway? Justice and the Integrity of the Person, by Cécile Fabre. Utilitas 21, no. 2 (June 2009): 23345 .

Fabre, Cécile. Whose Body Is It Anyway? Justice and the Integrity of the Person. Oxford: Oxford University Press, 2006.

88 I would like to thank Cécile Fabre, Nir Eyal, Alex Voorhoeve, Peter Vallentyne, Nic Tideman, Laura Valentini, Mike Otsuka, Matthew Weinzierl, and two anonymous reviewers for their helpful comments on earlier drafts of this article. Thanks also to Christine Tiefensee, Sebastian Köhler, and the other members of the Frankfurt School of Finance and Management's Philosophy Reading Group for their valuable suggestions. Finally, thanks to Richard Greene for proofreading earlier drafts of this article. 
Jensen, Rasmus, and Dermot Moran, eds. The Phenomenology of Embodied Subjectivity, vol. 71. New York: Springer, 2013.

Johns Hopkins Medicine. "What to Expect as a Living Donor." http://www .hopkinsmedicine.org/transplant/living_donors/expect.html.

Kidney Research uk. "Living with One Kidney." https://kidneyresearchuk.org/ kidney-health-information/questions-about-kidney-disease/living-with -one-kidney/.

Lippert-Rasmussen, Kasper. "Against Self-Ownership: There Are No Fact-Insensitive Ownership Rights over One's Body.” Philosophy and Public Affairs 36, no. 1 (Winter 2008): 86-118.

Mack, Eric. "Non-Absolute Rights and Libertarian Taxation." Social Philosophy and Policy 23, no. 2 (July 2006): 109-41.

—. "Nozickian Arguments for the More-than-Minimal State." In The Cambridge Companion to Nozick's Anarchy, State, and Utopia, edited by Ralf M. Bader and John Meadowcroft, 89-115. Cambridge: Cambridge University Press, 2011.

- "Prerogatives, Restrictions, and Rights." Social Philosophy and Policy 22, no. 1 (January 2005): 357-93.

McMahan, Jeff. The Ethics of Killing: Problems at the Margins of Life. Oxford: Oxford University Press, 2002.

Moazam, Farhat, Riffat Moazam Zaman, and Aamir Jafarey. "Conversations with Kidney Vendors in Pakistan.” Hastings Center Report 39, no. 3 (May-June 2009): 29-44.

Murphy, Liam, and Thomas Nagel. The Myth of Ownership: Taxes and Justice. Oxford: Oxford University Press, 2002.

National Kidney Foundation "A 'New Normal': Life on Dialysis— the First 90 Days." New York: National Kidney Foundation, 2007.

Nozick, Robert. Anarchy, State, and Utopia. New York: Basic Books, 1974.

Olson, Eric T. "Personal Identity." Stanford Encyclopedia of Philosophy (Summer 2017). https://plato.stanford.edu/archives/sum2017/entries/identity-per sonal.

Otsuka, Michael. Libertarianism without Inequality. New York: Oxford University Press, 2003.

Quinn, Warren. "Actions, Intentions, and Consequences: The Doctrine of Doing and Allowing." Philosophical Review 98, no. 3 (July 1989): 287-312.

Radin, Margaret Jane. "Property and Personhood." Stanford Law Review 34, no. 5 (May 1982): 957-1015.

Rothbard, Murray. The Ethics of Liberty. New York: New York University Press, 2002. 
"Law, Property Rights, and Air Pollution." Cato Journal 2, no. 1 (Spring 1982): 55-99.

Scheffler, Samuel. Rejection of Consequentialism. Rev. ed. Oxford: Oxford University Press, 1994.

Switzer, Galen, and Mary Dew. "Psychosocial Issues in Living Organ Donation." In The Transplant Patient: Biological, Psychiatric and Ethical Issues in Organ Transplantation, edited by Paula Trzepacz and Andrea DiMartini, 42-66. Cambridge: Cambridge University Press, 2000.

Thomson, Judith Jarvis. The Realm of Rights. Cambridge, MA: Harvard University Press, 1990.

Tideman, Nicolaus, and Peter Vallentyne. "Left-Libertarianism and Global Justice." In Human Rights in Philosophy and Practice, edited by Burton Leiser and Tom Campbell, 443-58. New York: Routledge, 2011.

Timmons, Mark. Moral Theory: An Introduction. Plymouth, Uk: Rowman and Littlefield Publishers, 2012.

Wajihuddin, Mohammed. "Pilgrims Protest $9 \%$ Service Tax on Haj, Likely to Move Supreme Court." Times of India, February 27, 2017.

Wheeler, Samuel. "Natural Property Rights as Body Rights." Noûs 14, no. 2 (May 1980): 171-93.

Wilkinson, T.M. "The Confiscation and Sale of Organs." Res Publica 13, no. 3 (September 2007): 327-37.

Young, H. Peyton. "Individual Contribution and Just Compensation." In The Shapley Value: Essays in Honor of Lloyd S. Shapley, edited by Alvin E. Roth, 267-78. New York: Cambridge University Press, 1988.

Zwolinski, Matt. "The Separateness of Persons and Liberal Theory." Journal of Value Inquiry 42, no. 2 (June 2008): 147-65. 